\title{
Indoor environmental quality evaluation in a hot and arid climate: a case study of a higher education office building
}

\author{
Yasmin Abdou ${ }^{1 *}$, Young Ki Kim ${ }^{1}$, Lindita Bande $^{1}$ \\ ${ }^{1}$ Architectural Engineering Department, United Arab Emirates University, UAE
}

\begin{abstract}
Indoor Environment Quality (IEQ) refers to the overall environmental quality within a building, especially as it relates to the health and comfort of the building's occupants. It includes several factors such as lighting levels and indoor air quality (IAQ). As humans spend a significant amount of time indoors; particularly at the workplace for up to 12 hours a day, the IEQ of the office greatly affects one's overall well-being, health with striking effects on productivity. As for IAQ, in severe cases, high levels of carbon dioxide $\left(\mathrm{CO}_{2}\right)$, particulate matter (PM), and humidity may cause headache, allergy, and asthma. A higher education (HE) office building located in United Arab Emirates University (UAEU) campus has been taken as a case study. Situated in the UAE, this is characterized by an extremely hot-arid climate. The HE building has been monitored using a set of advanced sensor devices to record indoor environmental data such as the measurements of temperature, relative humidity, lux level, particulate matter 2.5/10(PM 2.5/ 10), carbon dioxide (CO2), and total volatile organic compounds (TVOCs). Results of this paper aim to use the onsite numerical assessment and future POE assessment to verify the building's performance and discover where the operational gaps are. Better facility management strategies will be suggested to enhance the indoor environmental quality (IEQ) as well as more findings will be discussed in this paper.
\end{abstract}

\section{Introduction}

Climate change is the leading twenty-first century global issue. It has been increasingly discussed not as a debate of the scientific phenomenon or impacting evermore, but in terms of measurements to be taken to reduce its sincere projections and provide solutions for the consequences we are facing [1]. Through the ongoing study of climatic trends, rising extremity of weather events, along with depletion of the ozone layer, scientists are anticipating a large set of negative effects on natural and human systems [2]. A number of detected elements are causing a level of concern as their exposure is projected to increase with the escalating climatic conditions. These include overall heat, ultraviolet penetration, an increase of biological materials such as pollen, mold and infectious agents, and air pollutants, especially ozone and particulate matter [1].

To avoid these irregularities in the outdoor environment, people tend to spend most of their day irrespective of office work - indoors. In the United States people spend approximately $90 \%$ of their time in the indoor environment [3]. This emphasizes the importance of the indoor environment quality (IEQ) within buildings. Moreover, IEQ has a set of direct and indirect effects not only on the health and wellbeing of people inside the building but also the productivity levels especially in the office or workplace. Research shows that achieving favourable indoor climate conditions in the workplace can reduce employee absenteeism, reduce staff turnover, and increase occupant's productivity and satisfaction [4].

This paper is organized into four main sections. The first section is a literature review of IEQ and its relationship to health and well-being. Along with subsections on the different factors and thresholds of its parameters. This is followed by a section to describe the methodology of the study and the IEQ assessment. Using a case study of an office building on UAE campus physical monitoring devices and parameters were elaborated and used accordingly. The fourth section will present the results of each along with a discussion of monitoring results. A conclusion of this study will be presented in the last section.

\section{Literature review}

\subsection{IEQ effects at the workplace}

Since the early 2000 's, studies show that the IEQ is directly affected by environmental conditions outside the building [5]. Currently outdoor conditions have an alarmingly increasing concentration of several harmful pollutants due to global and climate change. Several pollutants were found to enter the indoor environment such as $\mathrm{NOx}, \mathrm{SO} 2, \mathrm{O} 3, \mathrm{CO}$, volatile and semi-volatile organic compounds (VOCs), PM, and microorganisms [6]. These contaminants provide several health effects on humans that vary in severity with their toxicity,

* Corresponding author: y.abdou@uaeu.ac.ae 
concentration and exposure time. However, one of the most popular effect is known as the sick building syndrome (SBS). SBS appears when people experience a series of uncomfortable health related symptoms. These symptoms may include eye, nose, and throat irritations, allergies, headaches, fatigue, asthma-like symptoms, and several more [7]. Although people may not know the exact cause of these syndromes, the syndrome may disappear once the affected person leaves the office or building.

Several studies at workplaces state that better IEQ decreases the sick building syndrome and increases user comfort which in turn increases individual work productivity [8]. Increasing work productivity has many economic benefits to companies, universities or schools. Green buildings have significantly higher rate of user satisfaction when it comes to IEQ as well as they allow a reduction in energy consumption [9]. Since a lot of energy is commonly used to overcool office buildings and that mostly causes discomfort to the user [10]. Focusing on the IEQ can reduce unnecessary energy cost while having positive effect on thermal comfort which in turn increases workplace productivity.

Other factors that affect the IEQ include the type of ventilation or air conditioning used in the office building and how well it is being maintained and operated [11]. For example, having a good air filtration system will help to significantly reduce the amount of particle matter (PM) or fine dust that enter the building from the outside, thus provide better air quality for the users. This stresses on the facility management methods as well as indoor user's behavioural activities.

This briefly summarizes most of the findings of the literature study of previous research related to the topic of IEQ effects. More details upon each study and its relative finding can be found in table 1 .

\subsection{IEQ factors}

According to the indoor environment handbook, IEQ includes 4 main factors: indoor air quality (IAQ), thermal comfort, lighting quality, and acoustic quality [12]. Each is measured by a set of parameters, has several control methods, and related issues; that can be found in table 2 .

Indoor air quality (IAQ) is an essential factor to asses the quality of the air within a building. Identifying and source controlling indoor pollutants can significantly decrease risks on human health and well-being. The building's ventilation system may be the most underestimated aspect of the indoor air pollution level. Thus, the design and maintenance of such systems are vital.

Thermal comfort is a subjective evaluation of one's satisfaction with the thermal environment [13]. It can differ from the perception of one person to another according to a set of factors such as age, gender, etc. Generally, thermal comfort is the most responsible factor for human's health, well-being, and productivity. As it has a direct effect on the body's respiratory system. For example, too cold environment or highly fluctuation temperature can trigger asthma and flu symptoms.

Sustaining comfortable lighting levels is crucial in the work environment. Major lighting issues need to be avoided such as glare, flickering, reflection, inconstant distribution, and lack of integration of daylighting and artificial lighting. Focusing on these issues can create a comfortable workplace environment that can increase work productivity. Having user's controllability further increases the lighting quality of the indoor space.

To make an indoor space perform better acoustically, control strategies can be implemented to limit unwanted noise and reverberation. Simple strategies involve using absorbing material, closing sound leaks, reducing contact sound transmission, and/or applying active noise control. Long-time exposure to disturbing noises can lead to a range of health issues such as stress, poor concentration, productivity losses in the workplace, and communication difficulties.

\subsection{IEQ parameter measures and thresholds}

Each IEQ factor can be measured by certain parameters. IAQ can be assessed by the amounts of fine and coarse particulate matter (PM2.5, PM10) measured in $\mu \mathrm{g} / \mathrm{m} 3$, carbon dioxide (CO2) measured in ppm, and total volatile organic compounds (TVOCs) measured in ppb. Long-time exposure with high percentages of such parameters can trigger a variety of health and well-being issues. WELL building standard and ASHREA 55 has been used to provide the maximum allowed values for each parameter; threshold values along with health effects can be found in table 2. [14] Similarly, thermal comfort can be measured by the indoor temperature in degrees Celsius and relative humidity percentage. Lighting can be measured by Lux, and acoustic quality by the sound levels in $\mathrm{dBA}$. 
Table 1. Literature review findings on IEQ effects at the workplace

\begin{tabular}{|c|c|c|c|c|}
\hline Title of the Study & $\begin{array}{l}\text { Region } \\
\text { Studied }\end{array}$ & $\begin{array}{l}\text { Study } \\
\text { Focus }\end{array}$ & Key Findings & Year \\
\hline $\begin{array}{l}\text { Patients and the sick } \\
\text { building syndrome. }\end{array}$ & America & $\begin{array}{l}\text { Suggest physician approaches to } \\
\text { identify disease in individual and } \\
\text { group effects on patients and analyse } \\
\text { impact of indoor environmental } \\
\text { exposure. }\end{array}$ & $\begin{array}{l}\text { Sick building syndrome can show several } \\
\text { recognizable symptoms that include } \\
\text { eye irritation, nose irritation, throat irritation, } \\
\text { headache, fatigue, asthma-like symptoms, } \\
\text { and more. }\end{array}$ & $\begin{array}{c}1994 \\
{[7]}\end{array}$ \\
\hline $\begin{array}{l}\text { Effect of outdoor air } \\
\text { pollution on indoor air. }\end{array}$ & Finland & $\begin{array}{l}\text { Measures Wintertime indoor and } \\
\text { outdoor particle size distribution in an } \\
\text { office building downtown } \\
\text { Helsinki. }\end{array}$ & $\begin{array}{l}\text { Proves that indoor air quality is directly } \\
\text { influenced by outdoor air quality, as the } \\
\text { PM2.5 and PM10 increase in both indoor and } \\
\text { outdoor air during a dust storm event. }\end{array}$ & $\begin{array}{c}2001 \\
{[5]}\end{array}$ \\
\hline $\begin{array}{l}\text { Indoor Air Quality in the } \\
\text { 21st Century: Search for } \\
\text { Excellence. }\end{array}$ & - & $\begin{array}{l}\text { Studies key principles for a new } \\
\text { philosophy of excellence. }\end{array}$ & $\begin{array}{l}\text { Prove better indoor air quality increases } \\
\text { productivity and decreases sick building } \\
\text { syndrome symptom. } \\
\text { Individual control of the thermal } \\
\text { environment should be provided to increase } \\
\text { user comfort. }\end{array}$ & $\begin{array}{c}2000 \\
{[8]}\end{array}$ \\
\hline $\begin{array}{l}\text { Thermal comfort and } \\
\text { behavioural strategies in } \\
\text { office buildings located in a } \\
\text { hot-arid climate. }\end{array}$ & Australia & $\begin{array}{l}\text { The effects of indoor climate on } \\
\text { thermal comfort levels and adaptive } \\
\text { behaviour of office workers. }\end{array}$ & $\begin{array}{l}\text { Shows office worker prefer adjusting the set } \\
\text { temperature of the building to } 22.21 \mathrm{C} \text { for } \\
\text { both seasons. As opposed to ASHRAE scale, } \\
\text { occurred at } 20.31 \mathrm{C} \text { in winter. Further } \\
\text { research can reduce overcooling cost with } \\
\text { positive effect on thermal comfort and } \\
\text { workplace productivity. }\end{array}$ & $\begin{array}{l}2001 \\
{[10]}\end{array}$ \\
\hline $\begin{array}{l}\text { Spatial mapping of occupant } \\
\text { satisfaction and indoor } \\
\text { environment quality in a } \\
\text { LEED platinum campus } \\
\text { building. }\end{array}$ & USA & $\begin{array}{l}\text { POE approach with GIS-based spatial } \\
\text { mapping method was used to analyse } \\
\text { and visualize the survey results of } \\
\text { building occupant satisfaction and the } \\
\text { measured indoor environment quality. }\end{array}$ & $\begin{array}{l}\text { Occupants complaints regarding thermal } \\
\text { comfort, reporting too cold., CO2 level was } \\
\text { also predominantly higher. Light levels in the } \\
\text { building were found higher than preferred as } \\
\text { artificial lighting was excessively used even } \\
\text { when daylight was available. }\end{array}$ & $\begin{array}{l}2014 \\
{[17]}\end{array}$ \\
\hline $\begin{array}{l}\text { Measured energy use and } \\
\text { indoor environment quality } \\
\text { in green office buildings in } \\
\text { China. }\end{array}$ & China & $\begin{array}{l}\text { Energy consumption and indoor } \\
\text { environment quality (IEQ) are } \\
\text { compared in green office buildings } \\
\text { with common ones through energy } \\
\text { data collection, physical parameters } \\
\text { measurement and satisfaction survey. }\end{array}$ & $\begin{array}{l}\text { User satisfaction in green buildings is } \\
\text { statistically significantly higher than those in } \\
\text { common buildings. Especially in the field of } \\
\text { thermal environment, IAQ, facilities and } \\
\text { operating \& maintenance. }\end{array}$ & $\begin{array}{l}2014 \\
{[19]}\end{array}$ \\
\hline $\begin{array}{l}\text { Comparative study on the } \\
\text { indoor environment quality } \\
\text { of green office buildings in } \\
\text { China with a long-term field } \\
\text { measurement and } \\
\text { investigation. }\end{array}$ & China & $\begin{array}{l}\text { This study analyses the subjective } \\
\text { questionnaires and objective } \\
\text { measurements of the indoor } \\
\text { environment quality (IEQ) in green } \\
\text { building. }\end{array}$ & $\begin{array}{l}\text { Results show that the green buildings in } \\
\text { China possess significantly higher IEQ } \\
\text { satisfaction level than conventional } \\
\text { buildings. This emphasises on the importance } \\
\text { of operation management and individual } \\
\text { control methods in the building. }\end{array}$ & $\begin{array}{c}2015 \\
{[9]}\end{array}$ \\
\hline $\begin{array}{l}\text { Perception of indoor } \\
\text { environment quality in } \\
\text { differently ventilated } \\
\text { workplaces in tropical } \\
\text { monsoon climates. }\end{array}$ & Sri Lanka & $\begin{array}{l}\text { The research investigates the } \\
\text { perception of indoor environment } \\
\text { quality (IEQ) in differently ventilated } \\
\text { workspaces. }\end{array}$ & $\begin{array}{l}\text { Air conditioning (AC) and ductless mini split } \\
\text { system air conditioning (MM) buildings were } \\
\text { rated more satisfactory than naturally } \\
\text { ventilated (NV) systems for overall comfort } \\
\text { of indoor environment condition. }\end{array}$ & $\begin{array}{l}2015 \\
{[11]}\end{array}$ \\
\hline $\begin{array}{c}\text { Occupant productivity and } \\
\text { office indoor environment } \\
\text { quality. }\end{array}$ & - & Literature study. & $\begin{array}{l}\text { The literature review shows both the } \\
\text { economic and health related benefits of good } \\
\text { IEQ. It illustrates the significance of the } \\
\text { impact of the IEQ on occupant comfort and } \\
\text { productivity. }\end{array}$ & $\begin{array}{c}2016 \\
{[4]}\end{array}$ \\
\hline $\begin{array}{l}\text { A review of semi-volatile } \\
\text { organic compounds } \\
\text { (SVOCs) in the indoor } \\
\text { environment: occurrence in } \\
\text { consumer products, indoor } \\
\text { air and dust. }\end{array}$ & - & $\begin{array}{l}\text { This review presents information on } \\
\text { semi-volatile organic compounds } \\
\text { (SVOCs) in consumer products to } \\
\text { link the information available for } \\
\text { chemicals in indoor air and dust with } \\
\text { their indoor sources. }\end{array}$ & $\begin{array}{l}\text { The relevance of this study was to emphasise } \\
\text { the importance of the indoor environment } \\
\text { quality, and human exposure risks associated } \\
\text { with VOCs. }\end{array}$ & $\begin{array}{l}2018 \\
{[18]}\end{array}$ \\
\hline
\end{tabular}


Table 2. IEQ factors, parameters, control methods, issues, threshold, and health effects

\begin{tabular}{|c|c|c|c|c|c|c|}
\hline $\begin{array}{c}\text { IEQ } \\
\text { Factors }\end{array}$ & Parameters & Control method & Issues & $\begin{array}{l}\text { Parameter } \\
\text { Measures }\end{array}$ & Threshold & Health Effects \\
\hline \multirow{4}{*}{ IAQ } & \multirow{4}{*}{$\begin{array}{c}\text { Pollution sources } \\
\text { Ventilation rate and } \\
\text { efficiency }\end{array}$} & \multirow{4}{*}{$\begin{array}{l}\text { Source control } \\
\text { Ventilation system } \\
\text { maintenance }\end{array}$} & \multirow{4}{*}{$\begin{array}{l}\text { Pollution } \\
\text { Fine dust }\end{array}$} & PM2.5 & $15 \mu \mathrm{g} / \mathrm{m} 3^{*}$ & \multirow{2}{*}{$\begin{array}{c}\text { Respiratory and cardiovascular } \\
\text { diseases including asthma, } \\
\text { myocardial ischemia, high } \\
\text { blood pressure and heart } \\
\text { disease }\end{array}$} \\
\hline & & & & PM10 & $50 \mu \mathrm{g} / \mathrm{m}^{*}$ & \\
\hline & & & & $\mathrm{CO} 2$ & 800 ppm* & $\begin{array}{l}\text { Increased risk of sick building } \\
\text { syndrome symptoms such as } \\
\text { headache }\end{array}$ \\
\hline & & & & TVOCs & 312 ppb* & $\begin{array}{l}\text { Dry throat, runny nose, asthma } \\
\text { attacks, poisoning, and cancer }\end{array}$ \\
\hline \multirow{2}{*}{$\begin{array}{l}\text { Thermal } \\
\text { Comfort }\end{array}$} & \multirow{2}{*}{$\begin{array}{l}\text { Temperature } \\
\text { Relative humidity } \\
\text { Air velocity } \\
\text { User activity }\end{array}$} & \multirow{2}{*}{$\begin{array}{l}\text { Air conditioning } \\
\text { system } \\
\text { Building design }\end{array}$} & \multirow{2}{*}{$\begin{array}{l}\text { Adaptation } \\
\text { Building } \\
\text { integration } \\
\text { Energy use }\end{array}$} & Temperature & $24^{\circ} \mathrm{C}-26^{\circ} \mathrm{C}^{* *}$ & Respiratory problems \\
\hline & & & & $\begin{array}{l}\text { Relative } \\
\text { Humidity }\end{array}$ & $65 \%-80 \% * *$ & $\begin{array}{l}\text { Microbial growth, skin drying, } \\
\text { irritation of mucus membranes, } \\
\text { and dry eyes }\end{array}$ \\
\hline $\begin{array}{l}\text { Lighting } \\
\text { Quality }\end{array}$ & $\begin{array}{c}\text { Luminance } \\
\text { Reflectance } \\
\text { Colour, temperature } \\
\text { View, and daylight }\end{array}$ & $\begin{array}{l}\text { Luminance } \\
\text { distribution } \\
\text { Artificial lighting } \\
\text { and daylighting } \\
\text { integration }\end{array}$ & $\begin{array}{l}\text { Daylight } \\
\text { relation to } \\
\text { thermal } \\
\text { comfort } \\
\text { Energy use }\end{array}$ & Lux level & $300-500$ lux* & $\begin{array}{l}\text { Headaches, circadian phase } \\
\text { disruptions, breast cancer, sleep } \\
\text { disorder, and depression }\end{array}$ \\
\hline $\begin{array}{l}\text { Acoustical } \\
\text { Quality }\end{array}$ & $\begin{array}{c}\text { Sound level } \\
\text { Absorption } \\
\text { Sound insulation } \\
\text { Reverberation time }\end{array}$ & $\begin{array}{l}\text { Acoustical control } \\
\text { Passive noise } \\
\text { control } \\
\text { Active noise control }\end{array}$ & $\begin{array}{l}\text { Vibrations and } \\
\text { annoyance } \\
\text { Long term } \\
\text { health effects }\end{array}$ & Sound level & $55 \mathrm{dBA}^{*}$ & $\begin{array}{l}\text { Hypertension, stress, poor } \\
\text { concentration, memory } \\
\text { retention and mental arithmetic }\end{array}$ \\
\hline
\end{tabular}

* WELL Building standard

** ASHREA 55

\section{Methodology}

\subsection{Case study building}

The case study building is located in United Arab Emirates University Campus, Al-Ain, UAE. Al-Ain climate is characterized to be hot-arid desert climate featured by its long, extremely hot summers $\left(38^{\circ} \mathrm{C}\right.$ average) and warm winters $\left(18^{\circ} \mathrm{C}\right.$ average), with average relative humidity at $60 \%$ [15]. It is a higher education office building known as the F1 building shown in figure 1. It houses three colleges (College of Engineering, College of Science, and College of Food \& Agriculture) through its three floors with an estimated number of 600 occupants that include faculty, students, researchers, and other staff. More information can be found in table 3 .

Table 3. Case study building information.

\begin{tabular}{|c|c|c|}
\hline \multirow{4}{*}{ Architecture } & Site & $\begin{array}{c}\text { P.O. BOX 15551, Al-Ain, } \\
\text { UAE }\end{array}$ \\
\hline & Use & $\begin{array}{c}\text { Office, labs and lecture } \\
\text { rooms }\end{array}$ \\
\hline & Building area & $7,120 \mathrm{~m}^{2}$ \\
\hline & Gross floor area & $21,360 \mathrm{~m}^{2}$ \\
\hline \multirow{3}{*}{ Mechanical } & Cooling & Campus district cooling \\
\hline & $\begin{array}{l}\text { Air Handling } \\
\text { Unit }\end{array}$ & $13 \mathrm{AHU}$ on the roof \\
\hline & Control & VAV \\
\hline \multirow{3}{*}{ Electrical } & Lighting & $\begin{array}{l}\text { T5 flounce lamp (office), } \\
\text { energy efficient light bulbs } \\
\text { in circulation }\end{array}$ \\
\hline & Illumination & $\begin{array}{l}\text { 400-500 Lux (Offices) and } \\
\text { 200-300 Lux (Circulation) }\end{array}$ \\
\hline & Renewable & N/A \\
\hline
\end{tabular}

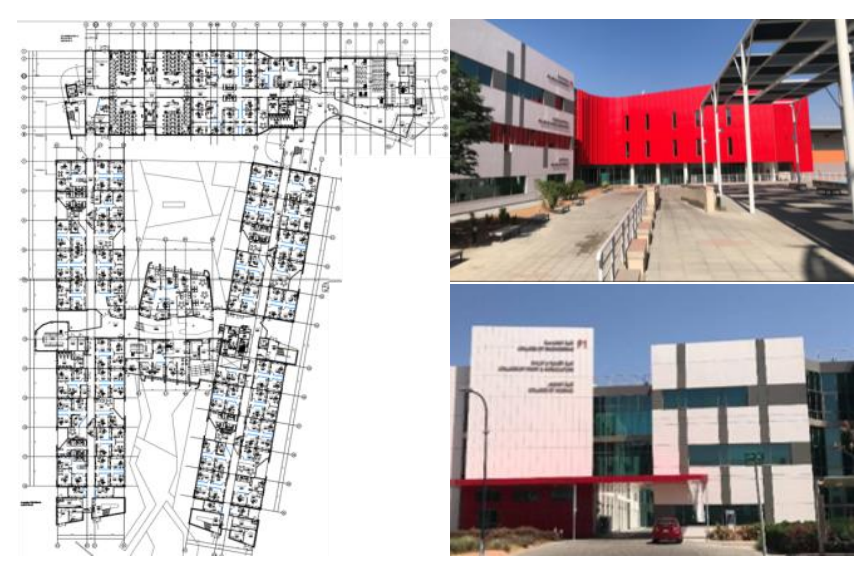

Fig. 1. Case study building plan and photos.

\subsection{Physical monitoring}

In order to evaluate the IEQ of the building, three devices have been used to gather data and monitor the trends for a set of environmental factors. First, the Air Mentor Pro (Model No.:8096-AP) is a smart air quality monitor that has been used to measure the PM2.5, PM10, $\mathrm{CO} 2$, and TVOCs concentrations in the indoor air. Secondly, the HOBO data logger has been used to measure the indoor temperature and relative humidity percentage. Lastly, PRECISION GOLD Multi-Function Environment Meter (Model N09AQ) has been used to measure the lighting and noise levels in the office building. 
The air mentor and HOBO devices have been set to record IAQ and thermal comfort parameters at 15minute intervals throughout 24 hours through the months of September to November 2019. Additionally, during set days indoor and outdoor real time data have been gathered using the air mentor at 2-3-minute intervals through the 8 working hours (from 8 a.m. to 4 p.m.) when the building was most occupied to verify results and further detect trends or flaws. The environment meter has been used to measure acoustics and lighting levels at $1 \mathrm{hr}$ intervals during the working hours for 1 week. Table 4 shows the devices used in this research and the paraments for each measure.

Table 4. Devices used, parameters measured, and measuring intervals

\begin{tabular}{|c|c|c|c|}
\hline Device & Image & $\begin{array}{c}\text { Parameters } \\
\text { Measured }\end{array}$ & $\begin{array}{c}\text { Measuring } \\
\text { Intervals }\end{array}$ \\
\hline $\begin{array}{l}\text { Air Mentor } \\
\text { Pro }\end{array}$ & & $\begin{array}{c}\text { PM2.5 } \\
\text { PM10 } \\
\text { CO2 } \\
\text { TVOCs }\end{array}$ & $\begin{array}{l}15 \min \\
2-3 \text { min }\end{array}$ \\
\hline HOBO & $\therefore$ & $\begin{array}{c}\text { Temperature } \\
\text { Relative } \\
\text { humidity }\end{array}$ & $15 \mathrm{~min}$ \\
\hline $\begin{array}{l}\text { PRECISION } \\
\text { GOLD } \\
\text { Environment } \\
\text { Meter }\end{array}$ & & $\begin{array}{l}\text { Lux level } \\
\text { Noise level }\end{array}$ & $1 \mathrm{hr}$ \\
\hline
\end{tabular}

To be able to sufficiently analyse and compare the data, 10 air mentor devices and 21 HOBO devices have been set up strategically throughout the three floors of the F1 building. They were located mainly around open offices, reception areas; and some closed offices, meeting rooms, classrooms, and labs. Figure 2 shows roughly the placement of each device on the floor plan.

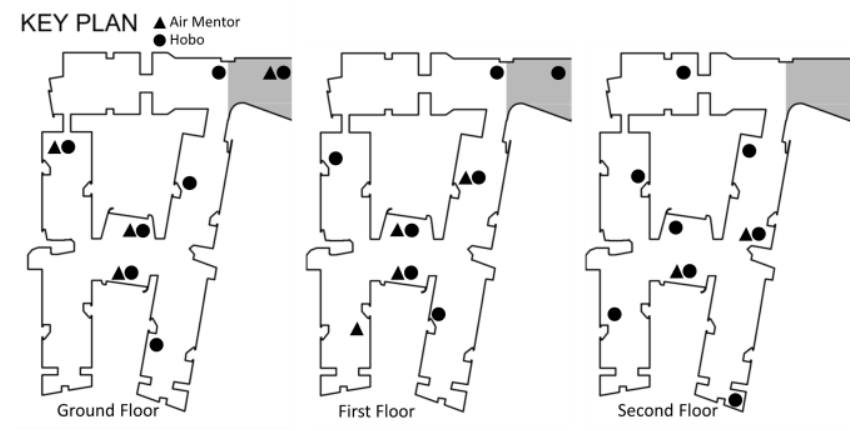

Fig. 2. Monitoring devices location in the floor plan

\section{Results and discussion}

\subsection{IAQ}

The overall indoor air quality of the office building showed no major flaws; however, some trends, facility management issues, and interesting user behavioural concerns have been discovered. The IAQ assessment was covered with the air mentor pro to record the physical measurements of PM2.5, PM10, $\mathrm{CO}_{2}$, and TVOCs levels in the air.

Starting off with PM2.5, results show the highest pollution levels above the threshold of $15 \mu \mathrm{g} / \mathrm{m} 3$. Especially around the entrances and reception areas (labelled GF2, FF6, and SF1 in figure 3), PM2.5 levels surpass the maximum threshold for up to $18 \%$ of the day, which takes place during the working hours from around 8 a.m. to 4 p.m. This can be directly related to the fact that entrance doors are usually left open and allow for air to enter without filtering. Furthermore, it has been verified when the outdoor PM2.5 levels were measured and showed a similar surpass in threshold levels for $27 \%$ of the day. As fine particulate matter (PM2.5) is very small in size it can travel deeply into the respiratory tract, reaching the lungs, causing many serious health effects on long exposure [16]. Additionally, a frequent trend was noticed every morning around the same reception and lounge areas, PM2.5 levels would increase up to severely dangerous amounts with the highest records at $166 \mu \mathrm{g} / \mathrm{m} 3$. The reason for this was tracked down to a user behavioural cultural norm of the use of what is locally known as Bukhoor. Bukhoor is cultural Arabian incense or act of burning used to remove odours and perfume clothes. Recently, several researchers and studies were raising its caution and potential risk to the lungs. There is very little regulation over the material burned and this triggers serious health risks to both workplaces and homes in the UAE. Likewise, PM10 levels show a similar trend, increasing at occupied working hours. The percentage of hours above threshold is only $2 \%$, as the larger particulate matter can be filtered more efficiently.

$\mathrm{CO}_{2}$ levels show a very clear trend of increase during occupied hours (shown in figure 3 ). Although it does not pass maximum allowable amount of $800 \mathrm{ppm}$ in open offices or entrances, a critical concern with the $\mathrm{CO}_{2}$ levels was found in the common meeting rooms. $\mathrm{CO}_{2}$ levels would reach up to $1000 \mathrm{ppm}$ and even the meeting room occupants would start to show symptoms of headache and lost focus. The ventilation system of the meeting room is advised to be revised, to keep it turned on even when the $\mathrm{AC}$ is not in use during the winter months. TVOCs levels show no concerns as the readings are all under the maximum threshold. This was expected as the building is relatively old and has no new materials introduced to cause an increase of TVOCs.

\subsection{Thermal Comfort}

Recurring complaints from building occupants initiated the concern of too cold indoor conditions. Additionally, building occupants mentioned flu symptoms to be triggered when being indoors, especially in the winter months when the temperature remains cold. 


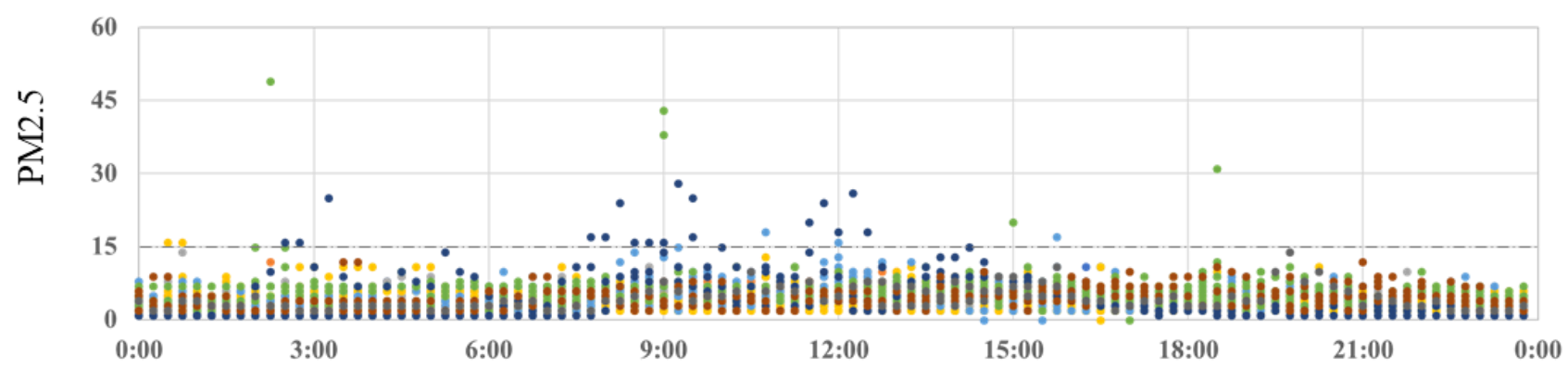

Time

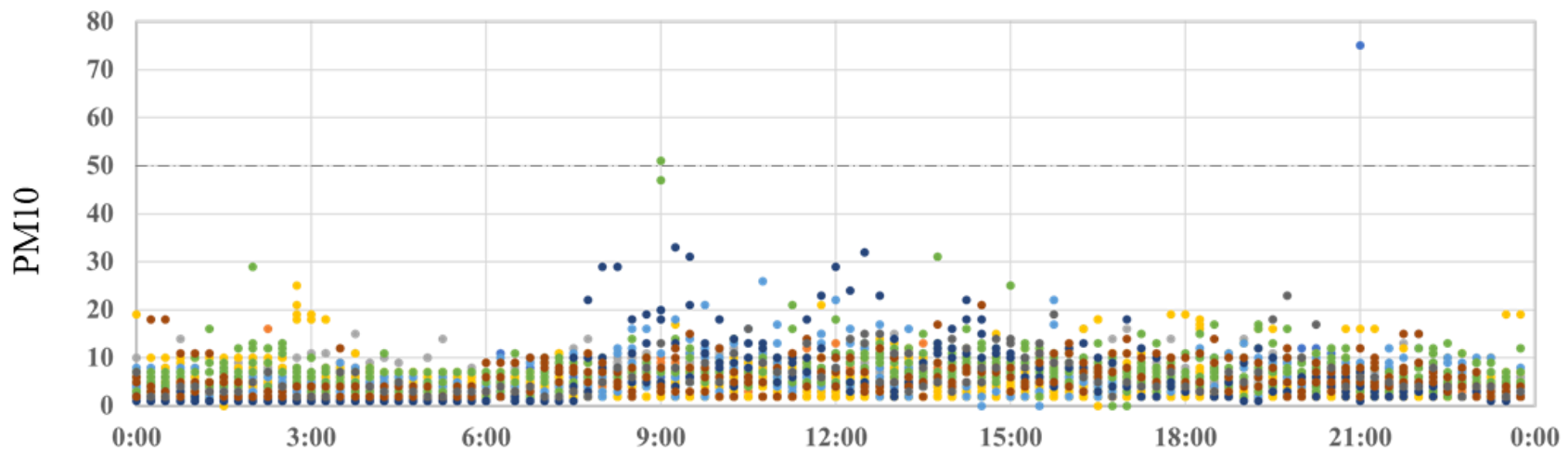

Time

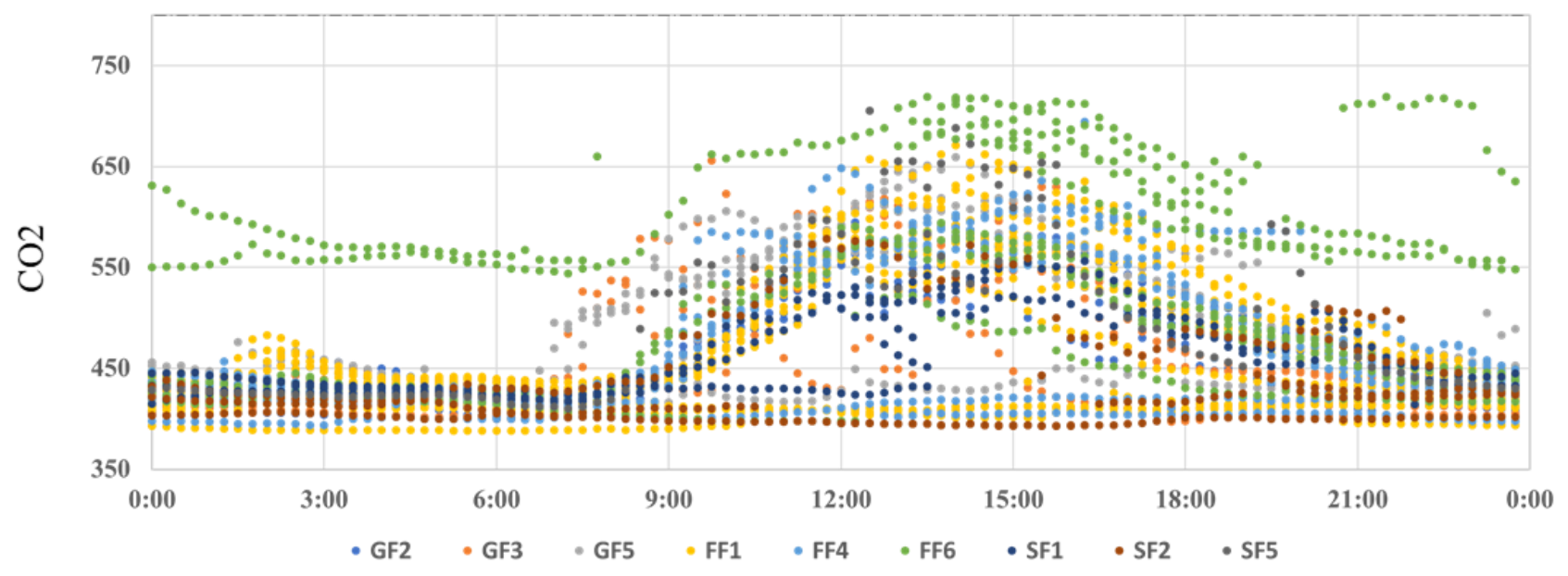

Fig. 3. IAQ monitoring 24 h. Graphs for PM2.5, $\mathrm{PM} 10$, and $\mathrm{CO}_{2}$ levels 
Thermal Comfort

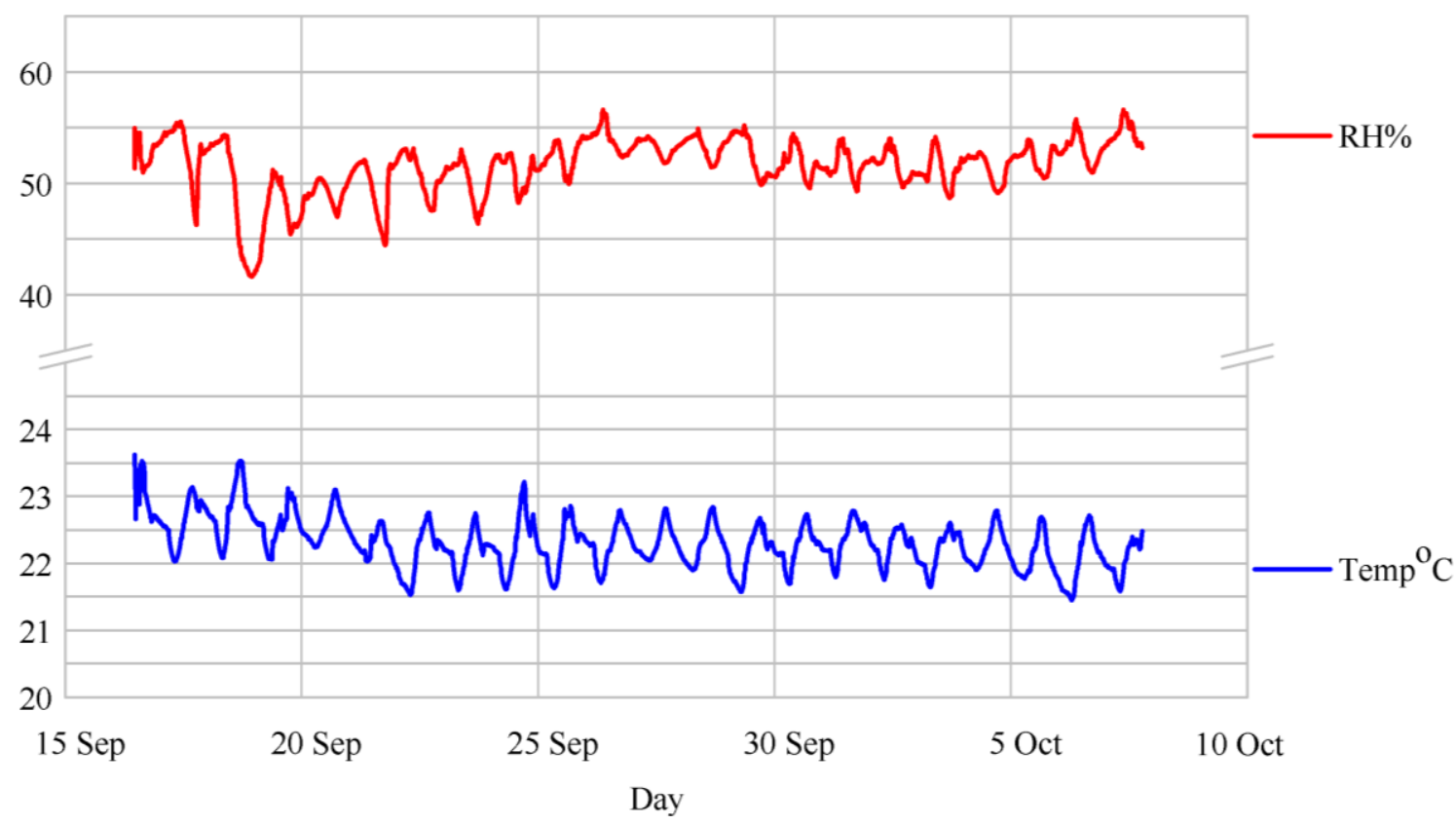

Fig. 4. Thermal comfort parameters monitoring for temperature and relative humidity

Table 5. Summary of IEQ monitoring results

\begin{tabular}{|c|c|c|c|c|c|c|}
\hline IEQ Factors & $\begin{array}{c}\text { Parameter } \\
\text { Measures }\end{array}$ & Threshold & Min & Max & Average & $\begin{array}{c}\text { \% above/ below } \\
\text { threshold }\end{array}$ \\
\hline \multirow{3}{*}{ IAQ } & PM2.5 & $15 \mu \mathrm{g} / \mathrm{m}^{3}$ & 0 & 166 & 4.7 & $18 \%$ \\
& PM10 & $50 \mu \mathrm{g} / \mathrm{m}^{3}$ & 0 & 75 & 5.8 & $2 \%$ \\
\hline & CO2 & $800 \mathrm{ppm}$ & 410 & 720 & 471 & $0 \%$ \\
\hline \multirow{2}{*}{ Thermal Comfort } & TVOCs & $312 \mathrm{ppb}$ & 97 & 234 & 142 & $0 \%$ \\
\hline & Temperature & $24^{\circ} \mathrm{C}-26^{\circ} \mathrm{C}$ & $19.4^{\circ} \mathrm{C}$ & $22.9^{\circ} \mathrm{C}$ & $21.8^{\circ} \mathrm{C}$ & $100 \%$ \\
\hline Lighting Quality & Relative Humidity & $65 \%-80 \%$ & 41.6 & 56.6 & $51.1 \%$ & $100 \%$ \\
\hline Acoustical Quality & Lux level & $300-500 \mathrm{lux}$ & $188 \mathrm{lux}$ & $807 \mathrm{lux}$ & $662 \mathrm{lux}$ & $89 \%$ \\
\hline
\end{tabular}

After analysing the results of monitoring the indoor temperatures and relative humidity, as seen in figure 4 , it clearly explains all the user complaints as both the indoor temperature and relative humidity show to be $100 \%$ below the threshold throughout the whole month of September. The average temperature being around $22^{\circ} \mathrm{C}$ and average relative humidity of $51 \%$ clearly both cause great discomfort to the building users. Al Ain weather is characterized to be dry and thus more focus should be placed upon the humidifying system within the building.

Although the facility manager claims to use humidifiers, no effect from them can be seen. Additionally, the set temperature of the building being $22^{\circ} \mathrm{C}$ is too cold per thermal comfort ASREA 55 standard and many complaints have been recorded regarding the temperature as it can't be controlled by the users. This is of great concern especially for the office workers that stay for more than 8 hours a day complaining regularly about the cold weather and the dryness. To overcome these conditions, some regular occupants brought their own mini humidifiers and blankets or jackets on their desks or chairs to feel more comfortable.

\subsection{Lighting and acoustics}

The lighting and acoustic levels in the building provided more concerns that can be tracked down to the facility management control as well as the building design, especially regarding the open office's location. As shown in table 5, the lighting level reach $89 \%$ above the threshold of the proposed 500 lux in open office areas with an average of 662 lux. This is because all the open offices are situated next to large windows but also usually have all the artificial light turned on. On top of increasing the lighting levels up to uncomfortable levels that may cause glare or headache, simply having more control on the number of artificial lights turned on can save a lot of the building's annual energy consumption and energy cost.

Furthermore, the noise level within the office building is relatively high, with about $50 \%$ above the threshold of $55 \mathrm{dBA}$. This is seen all around the open offices as noises from the corridors and nearby offices easily reach and get carried throughout the space. Additionally, the upper floor has very loud noises 
coming from the HVAC system that have initiated a couple of user complaints and should be reviewed. Air gaps around the staircase also cause loud noise that can disturb occupant's performance and concentration.

\section{Conclusion}

This paper highlights the IEQ especially within office buildings. As users spend up to $90 \%$ of their days indoors the IEQ can have many effects on the health and wellbeing of the people as well as their productivity level. Long-time exposures to indoor air pollutants may cause a range of health symptoms such as asthma, myocardial ischemia, high blood pressure and even heart disease. Moreover, increased risk of sick building syndrome symptoms occurs in bad indoor environment conditions. Studying and optimizing the IEQ provide many positive effects on the user's comfort and satisfaction rates as well as companies productivity level and relative economic benefits.

The IEQ can be analysed by 4 main factors: indoor air quality (IAQ), thermal comfort, lighting quality, and acoustical quality. This study uses 3 sensor devices to monitor several parameters within a case study higher education office building in Al Ain, UAE. For the IAQ, $\mathrm{PM}$ 2.5, PM10, $\mathrm{CO}_{2}$, and TVOCs levels have been

\section{References}

1. P. Schenck, A. Karim, A. Bracker, R. DeBernardo. Climate change, indoor air quality and health, University of Connecticut Health Center, 5-8, (2010)

2. Aries, M. Bluyssen, P M. Climate change consequences for the indoor environment, Heron, 54(1): 49-70, (2009)

3. A. Apter, A. Bracker, M. Hodgson, J. sidman, W. leung, The epidemiology of building-related complaints and illness. Occup Med State Art Rev; volume 94: 575-92, (1989)

4. Y. Al Horr , M. Arif, A. Kaushik, A. Mazroei, M. Katafygiotou, E. Elsarrag , Occupant productivity and office indoor environment quality: a review of the literature, Building and Environment, Volume 105: 369389, (2016)

5. I. Koponen, A. Asmi, P. Keronen, K. Puhto, M. Kulmala, the effect of outdoor air pollution on indoor air, Atmospheric Environment, Volume 35, pages 1465-1477, (2001)

6. D. Leung, Outdoor-indoor air pollution in urban environment: challenges and opportunity, Frontiers in Environmental Science, volume 2, pages 69, (2015)

7. M. Hodgson, E. Storey, Patients and the sick building syndrome, Susceptibility factors and specific syndromes, Volume 94: 335-343, (1994)

8. P. Fanger, Indoor Air Quality in the 21st Century: Search for Excellence, Indoor Air , volume 10: 68-73, (2001)

9. Z. Pei, B. Lin, Y. Liu, Y. Zhu, Comparative study on the indoor environment quality of green office buildings in China with a long-term field measurement and investigation, Building and Environment, Volume 84, pages $80-88,(2015)$ monitored and key findings highlight major concerns regarding user behaviour as the entrance doors are usually kept open by occupants and present higher concentration of PM2.5 which can create great health risks such as developing respiratory and cardiovascular diseases upon long-time exposure. Another notable issue is the use of "bukhoor" that initiates smoke and increases both PM2.5 and PM10 levels. The thermal comfort conditions in the building were $100 \%$ below set thresholds. Occupants have already initiated some complaints regarding the low temperature that should be in progress. Lighting was used excessively even around daylighting options and this created a lot of glare and increased lux levels. More study should be done to optimize the use of artificial lighting with daylighting and its further effects on user satisfaction as well as energy consumption. Acoustic quality was affected since the open offices were situated along the corridors without much sound insulation. Further studies will include a more detailed post-occupancy evaluation survey to assess the current IEQ conditions and test strategies to solve the concerns discovered through this study.

The authors would like to acknowledge the great support of the United Arab Emirates University for funding this study and allowing the use of it's building for research.

10. K. Cena, R. de Dear, Thermal comfort and behavioural strategies in office buildings located in a hot-arid climate, Journal of Thermal Biology, Volume 26, pages 409-414, (2001)

11. W. Gamage, S. Lau, Perception of indoor environment quality in differently ventilated workplaces in tropical monsoon climates, Procedia Engineering, Volume 118, pages 81-87, (2015)

12. P. Bluyssen, The Indoor Environment Handbook, (2009)

13. International WELL Building Institute, WELL V2 the next version of the well building standard, (2018)

14. ASHRAE Standard 55, Thermal Environmental Conditions for Human Occupancy, (2017)

15. Climate \& Weather Averages in Al Ain, Abu Dhabi, United Arab Emirates, (2019) retrieved from https://www.timeanddate.com/weather/united-arabemirates/al-ain/climate

16. New York state, Department of Health, Fine Particles Questions and Answers, (2018) retrieved from https://www.health.ny.gov/environmental/indoors/air/pmq _a.htm

17. Y. Hua, O. Gocer, K. Gocer, Spatial mapping of occupant satisfaction and indoor environment quality in a LEED platinum campus building, Building and Environment, Volume 79: 124-137, (2014)

18. L. Lucattini, G. Poma, A. Covaci, J. Boer, M. Lamoree, P. Leonards, A review of semi-volatile organic compounds (SVOCs) in the indoor environment: occurrence in consumer products, indoor air and dust, Chemosphere, Volume 20: 446-487, (2018)

19. B. Lin, Y. Liu, Z. Wamg, Z. Pei, M. Davies, Measured energy use and indoor environment quality in green office buildings in China, Energy and Buildings, Volume 129, pages $9-18,(2014)$ 